Revista Brasileira de Ensino de Física, v. 26, n. 4, p. 429 - 430, (2004)

www.sbfisica.org.br

Resenha

\title{
Um livro de Mecânica Quântica ansiosamente esperado
}

\author{
Diógenes Galetti \\ IFT, UNESP
}

Depois de longamente amadurecido em algumas versões preliminares, saiu o livro Mecânica Quântica do Prof. A.F.R. de Toledo Piza do Instituto de Física da Universidade de São Paulo (EDUSP, São Paulo, 632 pp., 2003). O texto, agora disponível na forma de livro, mantém as características básicas das primeiras versões (originalmente mimeografadas e, nas últimas versões, na rede) com as quais muitos estudantes de pós-graduação já tinham tomado contato. Não deixa de ser uma grata constatação, portanto, ver o lançamento do livro.

Se o material ensaiado ao longo de vários anos letivos foi sendo atualizado, assim também está o texto que agora aparece na forma impressa. Como resultado, a demora na publicação não sacrificou a atualização do conteúdo já que as aplicações apresentadas são bastante atuais e incorporam citações e uso de resultados de experiências recentes, mormente em Óptica Quântica, que não só reforçam conceitos básicos da Mecânica Quântica, como se tornam exemplos atraentes de tratamento e discussão para um livrotexto.

Da introdução do quantum de ação por Planck na teoria da radiação do corpo negro até a equação relativística de Dirac para o elétron em um campo coulombiano, o material coberto corresponde ao de um texto básico, típico de uma disciplina de pós-graduação de dois semestres. É interessante, porém, ressaltar que, não obstante seu objetivo explícito de introduzir os interessados nos meandros das técnicas operativas, dos conceitos e do sempre espinhoso debate sobre a interpretação da Mecânica Quântica, seja realizado de forma ortodoxa, o enfoque que baliza a introdução do leitor ao tema não é o tradicional.

De fato, os dois primeiros capítulos têm como tema condutor a necessidade, desde o princípio, da ruptura com a conceituação da Cinemática clássica quando se formula uma nova Mecânica para sistemas na escala atômica, e a introdução de uma nova conceituação, como concebida por Heisenberg e posteriormente implementado por Born, Jordan e o próprio Heisenberg. Desta forma, os objetos de dois índices de Heisenberg e suas versões matriciais posteriores têm importância central no texto por se constituírem no caminho que desembocará no formalismo de espaços vetoriais e na necessidade adicional de postulados interpretativos.

Com esse enfoque, essa abertura repousa sobre uma vertente histórica do desenvolvimento da Mecânica Quântica tradicionalmente menos trilhado por outros autores de livros-texto. Um livro muito interessante que também apresenta essa abordagem (dentro de uma recompilação brilhante da velha Mecânica Quântica) é o Quantum Mechanics de Tomonaga no seu volume I: Old Quantum Theory, mormente seu capítulo 5. É também verdade que o livro de van der Waerden, Sources of Quantum Mechanics faz todo o retrospecto histórico, uma vez que coleciona os textos originais, ali vertidos para o inglês quando necessário. Mas obviamente não há interesse explícito ali em transformar aqueles trabalhos em um material didático de uso direto.

Como resultado desse particular enfoque, a conseqüente introdução do conceito de espaços vetoriais e operadores lineares prontamente dá as ferramentas operacionais para se tratar inicialmente dos problemas típicos da mecânica quântica não-relativística. Este aspecto da abordagem pode se constituir numa virtude na medida em que o leitor rapidamente se prepara para a fase operacional do aprendizado do tema, e pode avançar sobre as sucessivas versões, cada vez mais elaboradas e realísticas, dos problemas de interesse. Por outro lado, isto se dará sem que ele acompanhe a vertente que traz das idéias de de Broglie até a bem estabelecida equação de onda de Schrödinger, ponto de partida de muitos textos. Esta, de fato, aparecerá como uma descrição possível (e facilitadora, do ponto 
de vista operacional) de uma equação fundamental, que governa a evolução temporal de um estado do sistema físico - como escrita no espaço vetorial - quando a teoria das representações é discutida. É neste sentido que o livro, no seu começo, exige um trabalho adicional do leitor: ater-se a uma linha de desenvolvimento da Mecânica Quântica costumeiramente não praticada, que exibe explicitamente as rupturas com o conceito clássico de Cinemática e a forma proposta por Heisenberg para sanar as dificuldades manifestadas.

A partir do terceiro capítulo o texto flui com uma perspectiva objetiva: sistemas físicos simples o suficiente para que sejam tratados exatamente quer seja por métodos algébricos ou pelo tratamento direto de equações diferenciais, seguidos por um capítulo de métodos de aproximação, quando são apresentados então os métodos mais conhecidos e usados. Passa por uma abordagem bastante rápida da teoria de momento angular e primeiras idéias de espalhamento por potenciais centrais no capítulo 5, para fechar o capítulo 6 com uma primeira abordagem do espectro do átomo de hidrogênio quando então é incluído o grau de liberdade de spin.

Nesse sentido, esta primeira metade do livro, até o capítulo 6, praticamente se impõe como o material a ser coberto num primeiro semestre, já que objetiva preparar o estudante a ter conhecimento suficiente para calcular desde sistemas físicos simples até o espectro do átomo de hidrogênio, levando em conta o grau de liberdade de spin e também os efeitos das interações com campos elétricos e magnéticos.

A segunda metade do livro aborda, em primeiro lu- gar, sistemas de partículas idênticas e seus tratamentos. É seguido pelos capítulos que tratam a interação da radiação com a matéria; grupos de transformações, simetrias e leis de conservação; teoria formal de espalhamento e finalmente as equações de onda relativísticas de Klein-Gordon e de Dirac. Com esse conjunto de temas mais avançados, reconhece-se o espírito de unidade de conteúdo - complementando o material da primeira metade do texto - que se espera seja dominado por um aluno de pós-graduação que deseje trabalhar em qualquer área de pesquisa em Física.

Na sua totalidade e abrangência, o texto é dimensionado para um curso de dois semestres bem recheados; assim, uma seleção do material a ser usado num curso pode ser feita. Por outro lado ainda, como o autor considera como pré-requisito um bom conhecimento de Física Matemática, há seções no texto em que a menção a algum material básico, por exemplo, equações diferenciais e polinômios clássicos, é feita diretamente, sem maiores digressões, o que pode demandar o acréscimo de exposições complementares que cubram as lacunas (eventualmente caracterizadas) nesses temas.

Este texto, como já longamente testado em salas de aula, constitui material rico para a formação em Mecânica Quântica de alunos de pós-graduação em Física, e os misprints presentes nesta certamente serão retocados nas próximas edições, que serão também bem vindas.

Mecânica Quântica, por A.F.R. de Toledo Piza, EDUSP, São Paulo, 632 pp. (2003). 